\title{
OPPORTUNITY RECOGNITION: GENDER AND FAMILY BUSINESS BACKGROUND COMPARISON
}

\author{
Christina \\ International Business Management, Universitas Ciputra Surabaya \\ nana@ciputra.ac.id* \\ Maureen Nuradhi \\ Interior Architecture, Universitas Ciputra Surabaya \\ maureen.nuradhi@ciputra.ac.id \\ Lili Kristanti \\ International Business Management, Universitas Ciputra Surabaya \\ Lili.kristanti@ciputra.ac.id
}

\begin{abstract}
Opportunity recognition is the first nascent step towards entrepreneurship. The previous study shows that gender and family business exposure plays a significant role for entrepreneurs to start a business. The objective of this study is to find out if there is any difference in opportunity recognition based on gender and family business background. The sample size of this study is 413 students who are taking the Entrepreneurial Global Innovation subject in the fourth semester at Universitas Ciputra Surabaya, comprising 234 males and 179 females. The data was taken at the end of the semester, which also coincided with the pandemic covid-19 situation. The data that has been collected is analyzed using an independent sample t-test. The result of the study reveals that there is a difference in opportunity recognition between students with family business backgrounds and students without a family business background. The other result of this study is that there is no difference in opportunity recognition between male and female. This study contributes to entrepreneurship education, especially in term of opportunity recognition and how it is different between students who have a family business background and those who do not. Further research needs to be done to ascertain whether gender equality in entrepreneurship has actually been achieved.
\end{abstract}

Keywords: Opportunity Recognition, Gender, Family Business, Entrepreneurship

\section{Introduction}

Entrepreneurship is linked with the stimulation of economic growth and a promoter of economic activity (Kusumawardani, Richard, 2020; Hassan et al., 2020). Entrepreneurs play an important role in Indonesia's economic sustainability and competitiveness. Santoso (2016) wrote in Jakarta Post that entrepreneurs are crucial drivers of economic growth. Entrepreneurs contribute to the development of economic growth through the development of ideas and business ventures (Turker and SonmezSelçuk, 2009; Hassan et al., 2020). Indonesia Ministry of Industry stated that hopefully there would be $4 \%$ of entrepreneurs in 2030. 
The academic sector has an important role in supporting the government target for increasing the numbers of entrepreneurs in Indonesia, since entrepreneurship can be promoted through entrepreneurship education (Fietze and Boyd, 2017; Saeed et al., 2015; Hassan et al., 2020). The academic sector can contribute to developing entrepreneurship by giving entrepreneurship education. Wei et al. (2019) stated that entrepreneurship education cultivates innovative talents, an important driving force for future development. Opportunity recognition is something that can not be separated from entrepreneurship. Entrepreneurs will have to involve and engage in three important tasks, which are opportunity recognition and exploitation, risktaking, and innovating (Wei et al., 2019; Chandler and Hanks, 1994). On his research, Hasan et al. (2020) research about opportunity recognition, entrepreneurship education, and entrepreneurial intention. Previous research done by Piperopoulos and Dimov, 2015 found that entrepreneurship education contributes to the development of students' entrepreneurial attitude, capabilities, and skills and the ability to seek new entrepreneurial opportunities. Manesh and Rialp-Criado (2019) found that entrepreneurship education in higher education enhances the influence of opportunity recognition on entrepreneurial intention.

Opportunity identification is the central element of entrepreneurship (Kirzner, 1979). A similar opinion was given by Joshi (2014), who stated that opportunity recognition is the first nascent step towards entrepreneurship. Shane and Venkataraman (2000) stated that the discovery of an opportunity is a necessary condition for entrepreneurship, but it is not enough, an entrepreneur should decide to exploit the opportunity. Based on previous research and arguments from Shane and Venkataraman (2000), Kuckertz et al. (2017) try to distinguish and define opportunity recognition and exploitation and also developed a scale to measure each of them.

Considering that opportunity recognition is a very important process at the beginning before the opportunity evaluation and development, it is important for educational institutions to find out and measure the student's opportunity recognition at the beginning, and find out the factors that influence it, so that the educational institution can develop the appropriate curriculum and activities to help the students improving.

The previous study shows that gender and family business exposure plays a significant role for entrepreneurs to identify opportunities and starting a business. Previous research related to opportunity recognition and gender has been done by DeTienne \& Chandler (2007), de Los Dolores González \& Husted (2011), Dahalan et al. (2013). DeTienne \& Chandler (2007) used two distinct samples which consist of 95 senior undergraduate students and189 entrepreneurs in high-technology industries in the United States. The result of this research showed that women and men use different processes of opportunity identification, but there was no difference in the innovativeness of the opportunities identified. Similar to the result of De Tienne \& Chandler (2007), de Los Dolores González \& Husted (2011) did research on 174 MBA students at a university in Northeastern Mexico, They also found that gender differences were not significant for either the number of opportunities identified or the innovativeness of such opportunities. Dahalan et al. (2013) researched 500 local populations in Lenggong Valley, Malaysia, and it was found that men and women differ in some aspects of idea generation for a business opportunity. The result of the research concludes that men are more active to discover business opportunity. From some of the previous research, it can be 
summarized that men and women use different processes of opportunity recognition, but there are no differences in terms of the number of opportunities and the innovativeness of the opportunities identified.

Indonesia Global Entrepreneurship Monitor (GEM) 2015/2016 report wrote that there is no gender gap in entrepreneurial activities in Indonesia. Indonesian women have an equal rate in entrepreneurial activities compared to their male counterparts. In 2019, Indonesia rank first in the Asia Pacific region in terms of the level of equality between women and men in entrepreneurship.

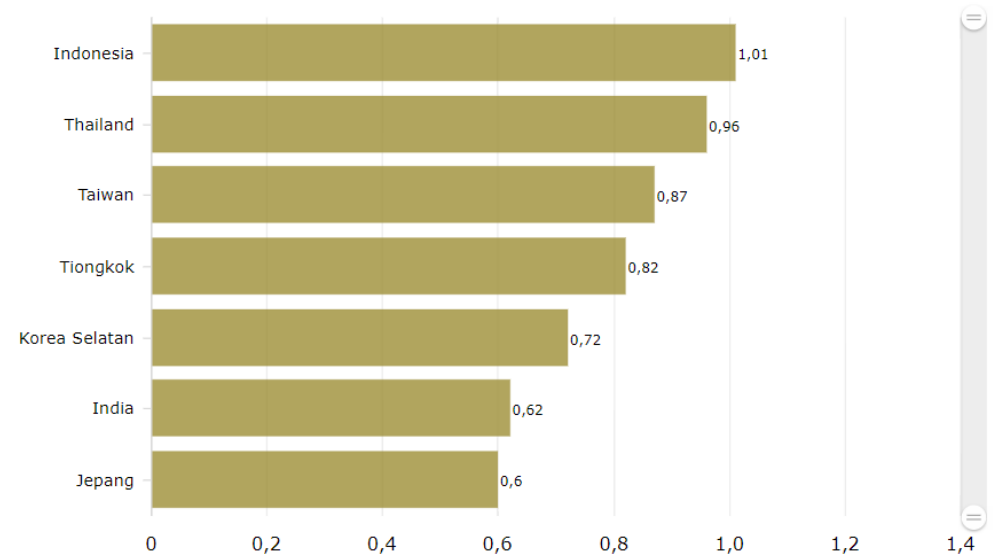

Figure 1. Female/Male total early-stage entrepreneurship ratio (2018/2019)

Source: databoks.katadata.co.id

From Figure 1. according to Global Entrepreneurship Monitor (GEM) 2019 report, it can be seen that the level of equality between women and men in entrepreneurship in Indonesia is among the highest in the Asia Pacific region, above Thailand, Taiwan, Tiongkok, South Korea, India, and Japan.

Some of the previous research already used business students as their samples. However, in De Tienne \& Chandler (2007), the majority of the respondents (76\%) had no prior entrepreneurial experience. Also, in de Los Dolores González \& Husted (2011) research, although they used MBA students as their sample, there was no information on whether the students had experience in starting a real business. Looking at this gap and the fact that there is no gender gap in entrepreneurial activities and the increasing number of women entrepreneurs in Indonesia, this research aims to find out if there is any difference in opportunity recognition based on gender, specifically on students who are starting their business. This research will contribute to entrepreneurship education development.

Apart from gender, family background is also an important factor that can influence entrepreneurship and opportunity recognition. Bakar et al. (2020) found that three factors can improve entrepreneurial opportunity recognition for graduate entrepreneurs, which are family background, individual desire, and education. This is in accordance with Gray (1998), who said that the main purpose of family is to transfer the social values and lifestyles in its members. Family background plays a vital role for an individual to become a good entrepreneur. The perception of entrepreneurship is influenced by the attitude of family members. (Kusumawardani 
and Richard, 2020). Since the family background is having an important role in entrepreneurship, especially in opportunity recognition, and there was no previous research that compares the opportunity recognition based on family business background, this research aims to find if there is any difference in opportunity recognition based on family business background, especially between those who have a family business and those who do not have.

The arrival of Covid, damage to international institutions, shifting ideologies, and changing patterns of international operations have also disrupted international business networks, widely viewed as essential to innovation, learning, access to resources, international expansion, and opportunity recognition (Lorenz et al., 2018; Pedersen, Soda, \& Stea, 2019; Zahra, 2020). The data collection was done during the pandemic situation, and it was expected to measure the student's opportunity recognition during the pandemic situation. Expectantly the result of this research can provide novelty, especially in opportunity recognition research and also give a contribution to entrepreneurship theory and education.

\section{Theoretical Framework}

\subsection{Opportunity Recognition}

Opportunity recognition is an interesting topic to be researched since it is related to the growth of business and constraints and also the fundamental of entrepreneurial behaviours (Joshi, 2014; Mariem et al., 2011; Minniti, 2009). Entrepreneurial behaviour is initiated when entrepreneurs able to recognize entrepreneurial opportunities (Ryu \& Kim, 2020). The ability to recognize or identify opportunity is very important for entrepreneurs since it is a crucial step for business creation and entrepreneurial performance (Mariem et al., 2011; Shane \& Venkataraman, 2000). Short et al. (2010) also stated that without an opportunity, entrepreneurial activities could not exist even though the individual has all the characteristics that influence the success of the venture creation process. The ability to recognize entrepreneurial opportunities is a major prerequisite for innovativeness (Jones and Barnir, 2019). Identifying and selecting the right opportunities for new business are the most important abilities of a successful entrepreneur (Stevenson et al., 1985, Ardichvili, 2003)

Many researchers have tried to define the opportunity and also opportunity recognition. In Oxford Learner's Dictionary, the opportunity is defined as a time when a particular situation makes it possible to do or achieve something. Jackson and Dutton (1988) define opportunities as a cognitive schema that are internally constructed by individuals (Karlesky, 2015). Kirzner (1973) defined the opportunity as the possibility of creatively combining resources and creating value to meet market demands (Ryu \& Kim, 2020). Some of the keywords for an opportunity based on the definition given is a time of particular situation, cognitive schema, creating value. Filser et al. (2020) summarize some definitions of the term opportunity that can be seen in Table 1 . 
Table 1. Definitions of The Term Opportunity

\begin{tabular}{|c|c|}
\hline Author & Definition \\
\hline $\begin{array}{l}\text { Shane and Venkataraman, } \\
2000\end{array}$ & $\begin{array}{l}\text { Situations in which new goods, services, raw } \\
\text { materials, and organizing methods can be } \\
\text { introduced and sold at greater than their cost of } \\
\text { production }\end{array}$ \\
\hline $\begin{array}{l}\text { Ardichvili, Cardozo and } \\
\text { Ray, } 2003\end{array}$ & $\begin{array}{l}\text { A range of phenomena that begin unformed and } \\
\text { become more developed through time }\end{array}$ \\
\hline Eckhardt and Shane, 2003 & $\begin{array}{l}\text { Situations in which new goods, services, raw } \\
\text { materials, markets, and organizing methods can } \\
\text { be introduced through the formation of new } \\
\text { means, ends, or means-ends relationships }\end{array}$ \\
\hline Gaglio, 2004 & $\begin{array}{l}\text { The chance to introduce innovative (rather than } \\
\text { imitative) goods, services, or processes to an } \\
\text { industry or economic marketplace." }\end{array}$ \\
\hline $\begin{array}{l}\text { Sarason, Dean, and Dillard, } \\
2006\end{array}$ & $\begin{array}{l}\text { Sources of opportunities are extant features that } \\
\text { provide the context for creating entrepreneurial } \\
\text { ventures }\end{array}$ \\
\hline Alvares and Barney, 2007 & $\begin{array}{l}\text { Competitive imperfections in markets were } \\
\text { created by the actions of entrepreneurs }\end{array}$ \\
\hline Short et al., 2010 & $\begin{array}{l}\text { Idea or dream that is discovered or created by an } \\
\text { entrepreneurial entity and that is revealed } \\
\text { through analysis over time to be potentially } \\
\text { lucrative }\end{array}$ \\
\hline Wood and McKinley, 2010 & $\begin{array}{l}\text { Opportunities are the outcome of social } \\
\text { construction, not preexisting entities subject to } \\
\text { detection by the entrepreneur }\end{array}$ \\
\hline Ramoglou and Tsang, 2016 & $\begin{array}{l}\text { The propensity of market demand to be } \\
\text { actualized into profits through the introduction of } \\
\text { novel products or services }\end{array}$ \\
\hline Ding, 2019 & $\begin{array}{l}\text { Neutral entities that emerge from an agent's } \\
\text { ability to develop a course of action that converts } \\
\text { an existing situation into a desired one }\end{array}$ \\
\hline
\end{tabular}

Researchers began to research and tried to define opportunity recognition. There are different views on whether the opportunity is recognized or it is created (Wasdani and Mathew, 2014; Filser et al. 2020). Based on the ontology of entrepreneurial opportunities, there are two different views about opportunity recognition (Shane, 2003). The first is opportunity recognition view based on the Kirzner $(1973,1979,1997)$ research. This view assumes that opportunities already exist in the market, and it is the task of entrepreneurs to find opportunities and exploit them. The second is opportunity creation based on Schumpeter's $(1934,1942)$ research. This view assumes that opportunities do not already exist but made by entrepreneurs. Opportunity is said to have been "created" when it is recognized endogenously through imagination and effectuation (Sarasvathy,2001).

Timmons (1994) defines opportunity recognition is not only a singular "Aha" experience. It is an iterative process through which insights are contemplated, new information is collected and considered, and knowledge is created over time (Lumpkin \& Lichtenstein, 2005). Based on the research done by Kirzner (1997) \& Shane (2003), Baron \& Ensley (2006) defined opportunity recognition as the process through which ideas for potentially profitable new business ventures are identified by specific persons. Schumpeter sees entrepreneurial opportunities as the 
combination of the new product, new method and new market, find new supply source and discover a new way to organize industrial organization.

Kuckertz (2017) tried to understand and measuring opportunity recognition. There are three characters of opportunity recognition, which are being (1) alert to potential business opportunities, (2) actively searching for them and (3) gathering information about new ideas on products or services. According to Ardichvili (2003), 5 factors influence the core process of opportunity recognition and development, which are (1) entrepreneurial alertness; (2) information asymmetry and prior knowledge; (3) social networks; (4) personality traits, including optimism, self-efficacy and creativity and (5) type of opportunity itself. According to Kickul et al. (2010), there are two related components of opportunity recognition, first is the searching for and obtaining of information leading to new opportunities, second is the recognition process by which new discoveries is made.

Having a family business background can influence how an individual identifies an opportunity. An individual who has entrepreneurial parents could shape how identifies and evaluates business opportunities (Joshi, 2014; Shane, 2000), though personality characteristics also matter in determining how entrepreneurs evaluate business opportunities. Similar to Joshi (2014), research done by Hsueh \& Zellweger (2018) finds that students who have the family business background, at least one of their parents owns and/or manages a business is more likely to found a company. When an individual's parents have a business, the individual exhibits a higher likelihood of becoming an entrepreneur compared to those whose parents have no business. Therefore, this study hypothesized that there is a significant difference between students who have and do not have a family business in opportunity recognition.

H1: There is a difference between students who have and do not have a family business in opportunity recognition

Some researches have been conducted to find out how gender difference effect opportunity recognition. Aderibigbe et al. (2014) research showed that gender did not independently predict entrepreneurial opportunity recognition. Opposites from Aderibigbe et al. research, research done by Gonzales-Alvares \& Solis-Rodriquez (2011) find that there is a difference between male and female in terms of entrepreneurial opportunities discovery. Men discover more business opportunities and possess more human and social capital compared to women. Research by Ryu \& Kim (2020) also shows that gender had the moderating effect in opportunity recognition and entrepreneurial intention relationship, although the size of the gender moderation effect was not directly related to the level of gender inequality in the sampled countries. Social Feminist Theory provides a theoretical framework in which gender may affect opportunity identification. Social Learning Theory suggests that men and women are different because of their unique learning experiences. Gender differences showed by Social Feminist Theory, and also Social Learning Theory suggests that women and men may also differ significantly in the processes of opportunity identification (DeTienne \& Chandler, 2007). Therefore, this study hypothesized that there is a significant difference between male and female in opportunity recognition

H2: There is a significant difference between male and female in opportunity recognition 


\subsection{Entrepreneurial Global Innovation}

Entrepreneurial Global Innovation (EGI) is a subject that is incorporated into the entrepreneurship curriculum at Universitas Ciputra Surabaya. The subject is taken by fourth-semester students. It is mandatory for business management students and optional for non-business management students. This course is a project-based course with design a design thinking process that facilitates students to be able to plan innovations in the form of validated strategic planning which aims at aspects of growth and sustainability towards global standard ventures. Students are expected to create added value based on scientific concepts and entrepreneurship by exploring opportunities at the national and/or global level that can generate added value. In the learning design, there were four weeks allocated to discuss and learn about opportunity recognition by doing the four external forces analysis.

There are 10 study guilds in EGI which are industry-specific class such as (1) Family Business, (2) Trading, (3) Tourism Hospitality and Culinary, (4) Fashion, (5) Marketing and Visual Communication, (6) Personal and Professional Development and Service, (7) Interior Architecture, Construction, and Engineering, (8) Social, (9) Technology, (10) UC-Ventures. Students work on real business projects that can be done either individually or in groups. Students who join the family business guild will do their project individually based on the family business they have.

\section{Research Methods}

This research is quantitative. The population taken in this study are the students who take Entrepreneurial Global Innovation (EGI) subject in the fourth semester at Universitas Ciputra Surabaya. The lesson started in January 2020 and ended in May 2020 and consists of 16 meetings, including the mid-term and final exam. Due to the covid-19 case that was announced by Mr Jokowi at the beginning of March 2020 , the lecturing process that originally took place offline turned into online. The students are still asked to execute the initial planning of their business project even though it was in the pandemic situation.

The total of students who take the subjects is $\mathbf{5 7 5}$ students. The sampling technique used in this research is total population sampling. Total population sampling is a technique where the entire population meet the criteria are included in the research being conducted (Etikan et al., 2016). The data was collected through a questionnaire survey using google form. Out of 575 students who take the EGI subject, only 413 students (71.8\%) who fill the Questionnaire. There are five questions used to measure opportunity recognition. The instrument was adopted from Kuckertz et al. (2017). A five-point scale ranging from "1=Totally disagree" to "5=Totally agree" was used to measure the scales of the opportunity recognition. The Questionnaire began to be distributed in week 15 of lectures. Statistical analysis using independent t-test was performed to assess any significant differences in entrepreneurial Recognition based on gender and family business background.

Validity and reliability test are performed to check the instruments. Validity is to measure how well an instrument that is developed measures the particular concept. 
Reliability test is to measure how consistent an instrument measures whatever concept it is measuring. In general, reliabilities less than 0.60 are considered poor, those in the 0.70 range are acceptable, and those over 0.80 are good (Sekaran and Bougie, 2016).

\section{Results and Discussion}

\section{Demography of the Respondents}

The respondent's demography is presented in Table 1 . The result shows that $56.7 \%$ $(n=234)$ of the respondents were male, and $43.4 \% \quad(n=179)$ were female. Concerning family business background, the majority of the respondents, which is $70.2 \%(\mathrm{n}=290)$ have a family business, and $29.8 \%(\mathrm{n}=123)$ do not have a family business.

Table 1. Demographic Profile of Respondents

\begin{tabular}{llll}
\hline $\begin{array}{l}\text { Demographic } \\
\text { Profile }\end{array}$ & Categories & Frequency & $\begin{array}{l}\text { Percentage } \\
(\%)\end{array}$ \\
\hline Gender & Male & 234 & 56.7 \\
& Female & 179 & 43.4 \\
\hline Have a Family & Yes & 290 & 70.2 \\
Business & No & 123 & 29.8 \\
& & & \\
\hline
\end{tabular}

\section{Validity}

The validity test performed using Pearson correlation with 5\% significance level using SPSS. The R-value is obtained from the R table, and its value is 0.0969. The Pearson correlation test result is compared to the $\mathrm{R}$ table value, and the item of the Questionnaire is valid if the Pearson correlation result > R-value. The validity test results are presented in Table 2 . Based on the validity test results, all the items in the Questionnaire have met the validity test criteria and declared as valid.

Table 2. Validity Test Result

\begin{tabular}{llll}
\hline Item & $\begin{array}{l}\text { Result } \\
\text { Correlation }\end{array}$ & R-Value & Description \\
\hline Statement 1 & 0.804 & 0.0969 & Valid \\
\hline Statement 2 & 0.820 & 0.0969 & Valid \\
\hline Statement 3 & 0.842 & 0.0969 & Valid \\
\hline Statement 4 & 0.797 & 0.0969 & Valid \\
\hline Statement 5 & 0.816 & 0.0969 & Valid \\
\hline
\end{tabular}

\section{Reliability}

Table 3. presents the Cronbach's alpha value for opportunity recognition. The Cronbach's alpha result is 0.876, and according to (Sekaran and Bougie, 2016) 
Cronbach's alpha over 0.80 is considered as good. This means all items were internally consistent and reliable to assess opportunity recognition.

Table 3. Reliability Test Result

\begin{tabular}{llll}
\hline Variable & $\begin{array}{l}\text { Cronbach's } \\
\text { Alpha }\end{array}$ & N of Items & Result \\
\hline $\begin{array}{l}\text { Opportunity } \\
\text { Recognition }\end{array}$ & 0.874 & 5 & Reliable \\
\hline
\end{tabular}

\section{Hypothesis Testing Findings}

Table 4. t-test Result Comparing Family Business Background in opportunity Recognition

\begin{tabular}{lllllll}
\hline $\begin{array}{l}\text { Have } \\
\begin{array}{l}\text { Family } \\
\text { Business }\end{array}\end{array}$ & $\mathrm{N}$ & Mean & SD & $\mathrm{t}$ & $\mathrm{df}$ & $\begin{array}{l}\text { Sig (2 } \\
\text { tailed) }\end{array}$ \\
\hline Yes & 290 & 19.35 & 2.966 & 2.691 & 411 & 0.007 \\
No & 123 & 18.48 & 3.116 & & & \\
\hline
\end{tabular}

Table 4. presents the independent t-test result comparing family business background in opportunity recognition. It can be concluded that there is a significant difference in opportunity recognition between students who have a family business and those who do not have a family business. Students who have family business background tend to have a higher mean score in opportunity recognition compared to those who do not have. Family is the closest to the students and play an important role in influencing student in entrepreneurship (Bakar et al., 2020; Van Auken et al., 2006). The family becomes a role model for the student and provide a strong influence on motivating children to entrepreneurship (Bakar et al., 2020; Kirkwood, 2009). The results obtained are in accordance with Ardichvilli (2003) research which stated that entrepreneurial alertness, prior knowledge and social networks influence opportunity recognition and development. Students who have family business background were first exposed to the parent's network and business. It is reasonable if the mean score of the students who have a family business background is higher than those who do not have.

Table 5. t-test Result Comparing Male and Female in opportunity Recognition

\begin{tabular}{lllllll}
\hline Gender & $\mathrm{N}$ & Mean & SD & $\mathrm{t}$ & $\mathrm{df}$ & $\begin{array}{l}\text { Sig (2 } \\
\text { tailed) }\end{array}$ \\
\hline Male & 234 & 18.98 & 3.203 & -0.868 & 411 & 0.386 \\
Female & 179 & 19.24 & 2.799 & & & \\
\hline
\end{tabular}

Table 5. presents the independent t-test result comparing male and female in opportunity recognition. It can be concluded that there is no significant difference in opportunity recognition between male and female students. The results obtained are different from the predetermined hypothesis and contradicts some of the previous research. Previous researchers affirmed that male are more active to 
discover business opportunity rather than female (Dahalan et al., 2013). DeTienne $\&$ Chandler (2007) find that women and men use different processes of opportunity identification, but there was no difference in the innovativeness of the opportunities identified. It was stated that they had premature conclusion based on the result which may be caused by the small proportion of the women sample, which was $13 \%$ of the total sample. De Los Dolores González \& Husted (2011) also found that gender differences were not significant for either the number of opportunities identified or the innovativeness of such opportunities. The result of previous researches show that there are differences in the process of opportunity recognition, but there are no differences in number and innovativeness of the opportunities identified.

The absence of differences in the opportunities recognition between male and female can be caused by the different condition of gender equality in different countries. Indonesia's government has been trying to encourage gender quality. This can be seen from The National Gender Mainstreaming Policy enacted in 2000 (through The Presidential Decree in) guides the National Long-term Development Plan (RPJPN) 2005- 2025 which confirms the Indonesian government's commitment to gender equality with specific laws in place and aligning the National Development Agenda Sustainable Development Goal number 5 which is gender equality (United Nations Development Programme, 2017). Improved conditions in terms of gender equality can be seen from the Global Gender Gap Index. Indonesia was 95th out of 136 countries in 2014, and improved the position to 92 out of 145 countries in 2015 and rank 85th out of 153 countries in 2020. From the Global Entrepreneurship Monitor Report in 2015/2016, it is known that already no gender gap in entrepreneurial activities in Indonesia. Indonesian women have an equal rate in entrepreneurial activities compared to their male counterparts. Even in 2019, Indonesia ranked first in the Asia Pacific region in terms of the level of equality between women and men in entrepreneurship. Country's condition also affects the growth of women entrepreneurs. Minniti (2009) found that the highest percentages of women trying to start new businesses are found in poorer countries, in the formal labour market are more difficult to obtain.

The different result from previous research can also be caused by different criteria of the sample. Most previous research uses serial entrepreneurs who already have experience in the formation of multiple businesses. The sample of this research are students who are running their real project business which may be the first experience for them running a business.

\section{Conclusion and Implications}

The analysis of differences in opportunity recognition based on family business background and gender was carried out. The results showed that there are significant differences in opportunity recognition between students who have a family business background and those who do not have. Students with family business background tend to have higher mean scores compared to those who do not have a family business. Another result of this study is there is no significant differences in opportunity recognition between male and female students.

From a theoretical point of view, the study of opportunity recognition is very important since it is fundamental to entrepreneurial behaviour and has a crucial role 
in venture creation. The result of this study will implicate to entrepreneurs, entrepreneurship theory development and entrepreneurship education.

The practical findings of this study provide insights for universities, parents and students. Previous research by Manesh and Rialp-Criado (2019); Hasan et al. (2020) found that entrepreneurship education in higher education enhances the influence of opportunity recognition. Since the result of this study show that there is a significant difference in opportunity recognition based on family business background, and students with family business background tend to have a higher mean score in opportunity recognition, it will be great if it can be embedded in the entrepreneurship education curriculum to involve the parents in the learning process.

\section{Suggestion for future research}

Although the data collection was done during the pandemic situation, it is not certain whether the pandemic conditions affect the opportunity recognition result, since the Questionnaire was adopted from Kuckertz et al. (2017) and there was no modification on the Questionnaire to adjust the situation. Further research and modification on the opportunity questionnaire are needed to get a better insight into whether the pandemic situation influence opportunity recognition and how does it affect opportunity recognition. Further research also needs to ascertain whether gender equality in entrepreneurship has actually been achieved, and therefore, there is no significant difference based on the gender on entrepreneurship. Future research also can measure and compare the opportunity recognition on a different type of entrepreneurs, such as students entrepreneurs, early-stage entrepreneurs and serial entrepreneurs.

\section{References}

Aderibigbe, J., Abu., Hassan, S., Oluwafemi, O., Oluwasanmi, O. (2014). Social Network and Human Capital as Determinants of Entrepreneurial Opportunity Recognition in Nigeria. International Journal of Public Administration and Management Research, 2(2), 116-128.

Alvarez, S. A., Barney, J. B. (2007). Discovery and Creation: Alternative Theories of Entrepreneurial Action. Strategic Entrepreneurship Journal, 1(1-2), 1126. doi: 10.1002/sej.4.

Ardichvili, A., Cardozo, R., \& Ray, S. (2003). A theory of entrepreneurial opportunity identification and development. Journal of Business Venturing, 18(1), 105-123.

Bakar, M.S.A., Hassan, S., Taa, A., Yasin, A., Suhaimi, S. (2020). Factor Improving Entrepreneurial Opportunity Recognition for Graduate Entrepreneur. Journal of Critical Reviews, Vol 7(5). 125-128.

Baron, R. \& Ensley, M. (2006). Opportunity Recognition as the Detection of Meaningful Patterns: Evidence from Comparisons of Novice and Experienced Entrepreneurs. Management Science.

Chandler, G. N., \& Hanks, S. H. (1994). Founder competence, the environment and venture performance. Entrep. Theory Pract. 18, 77-89.

Dahalan, N., Jaafar, M., \& Rosdi, S. A. M. (2013). Local Community Readiness in Entrepreneurship: Do Gender Differ in Searching Business Opportunity. 
Procedia - Social and Behavioral Sciences, 91, 403-410. doi:10.1016/j.sbspro.2013.08.437

Delmar, F., Davidson, P. (2000). Where do they come from? Prevalence and characteristics of nascent entrepreneurs. Entrepreneurship \& Regional Development, 12, 1-23. doi: 10.1080/089856200283063

Detienne, D. \& Chandler, G. (2007). The Role of Gender in Opportunity Identification. Entrepreneurship Theory and Practice. 31. 365 - 386.

Ding, T. (2019). Understanding the Design of Opportunities: Re-evaluating the Agent-Opportunity Nexus through a Design Lens. Journal of Business Venturing Insights, 11. doi: 10.1016/j.jbvi.2018.e00108.

Eckhardt, J. T., and S. A. Shane. (2003). Opportunities and Entrepreneurship. Journal of Management, 29(3), 333-49. doi: 10.1177/014920630302900304.

Etikan, I, Musa, S.A., Alkassim, R.S. (2016). Comparison of Convenience Sampling and Purposive Sampling. American Journal of Theoretical and Applied Statistics. 5(1), 1-4.

Fietze, S. and Boyd, B. (2017), "Entrepreneurial intention of Danish students: a correspondence analysis". International Journal of Entrepreneurial Behavior and Research, 23(4), 656-672.

Filser, M., Tiberius, V., Kraus, S., Zeitlhofer, T., Kailer, N., \& Müller, A. (2020). Opportunity Recognition: Conversational Foundations and Pathways Ahead. Entrepreneurship Research Journal (published online ahead of print 2020). doi: 10.1515/erj-2020-0124

Gaglio, C. M. (2004). The Role of Mental Simulations and Counterfactual Thinking in the Opportunity Identification Process. Entrepreneurship Theory and Practice, 28(6), 533-52. doi.org/10.1111/j.1540-6520.2004.00063.x.

de los Dolores González, M. and Husted, B.W. (2011), "Gender, human capital, and opportunity identification in Mexico", International Journal of Gender and Entrepreneurship, 3(3), 236-253. doi.org/10.1108/17566261111169322

Gray, C. (1998). Enterprise \& Culture. Routledge, London.

Hassan, A., Saleem, I., Anwar, I., \& Hussain, S. A. (2020). Entrepreneurial intention of Indian university students: the role of opportunity recognition and entrepreneurship education. Education + Training, 62(7/8), 843-861. doi:10.1108/et-02-2020-0033

Hsueh, J., Zellweger, T.M. (2018) A gift or a curse? The influence of family business background on next-generation entrepreneurship.

Jackson, S. E., \& Dutton, J. E. (1988). Discerning threats and opportunities. Administrative Science Quarterly. 370-387.

Karlesky, M. (2015). Identifying Entrepreneurial Opportunities: Cognition and Categorization in Nascent Entrepreneurs.

Kirzner, I. M. 1973, Competition and entrepreneurship, Chicago: University of Chicago Press.

Kusumawardani, K.A., Richard. (2020). Family Comes First: An Investigation on Entrepreneurial Intention among Chinese Indonesian Gen Z. International Journal of Family Business Practices, 3(1), Vol 3, Issue 1, 39-54.

Jackson, S. E., \& Dutton, J. E. (1988). Discerning threats and opportunities. Administrative Science Quarterly, 370-387

Jones, R. J., Barnir. A. (2019). Properties of Opportunity Creation and Discovery: Comparing Variation in Contexts of Innovativeness. Technovation, 79, 110. doi: 10.1016/j.technovation.2018.02.014. 
Joshi, M. (2014). Entrepreneurial Opportunity Recognition and Growth of Venture via Strategic Alliance: A Case Study of RTAP. International Journal of Strategic Business Alliances. 4.

Katadata. (2019). Kesetaraan Gender dalam Wirausaha Indonesia Tertinggi di Asia Pasifik. Retrieved December 16, 2020, from https://databoks.katadata.co.id/datapublish/2019/10/15/kesetaraan-genderdalam-wirausaha-indonesia-tertinggi-di-asia-pasifik

Kirkwood, J. (2009). Motivational factors in a push-pull theory of entrepreneurship, Gender in Management: An International Journal, 25(5), pp. 346-364

Kirzner, I. M. 1973. Competition and Entrepreneurship. Chicago and London: University of Chicago Press.

Kirzner IM (1979) "Perception, Opportunity and Profit". Chicago: University of Chicago Press.

Kirzner, I. (1997). Entrepreneurial Discovery and the Competitive Market Process: An Austrian Approach. Journal of Economic Literature 35 (1): 6085.

Kuckertz, A., Kollmann, T., Krell, P. and Stöckmann, C. (2017), Understanding, differentiating, and measuring opportunity recognition and opportunity exploitation. International Journal of Entrepreneurial Behavior \& Research, Vol. 23 (1). 78-97.

Manesh, SMZE and Rialp-Criado, A. (2019). "International ecopreneurs: the case of ecoentrepreneurial new ventures in the renewable energy industry". Journal of International Entrepreneurship, 17 (1), 103-126.

Mariem, B., Aloulou, W. J., Boujelbene, Y. (2011). Identifying entrepreneurial opportunities by nascent entrepreneurs in Sfax Region. Conference: 8th European Summer University at Universidad de Sevilla, Volume: 1-20

Minniti, M. (2009). Gender Issues in Entrepreneurship. Foundations and Trends $®$ in Entrepreneurship, Vol. 5 (No. 7-8). 497-621

Lorenz M.P., Ramsey J.R., Richey R.G. (2018). Expatriates' international opportunity recognition and innovativeness: The role of metacognitive and cognitive cultural intelligence. Journal of World Business, 53(2), 222-236.

Lumpkin, G.T., Lichtenstein, B.B. (2005). The Role of Organizational Learning in The Opportunity Recognition Process. Entrepreneurship: Theory and Practice 2005,29(4):451-472

Pedersen T., Soda G., Stea D. (2019). Globally networked: Intraorganizational boundary spanning in the global organization. Journal of World Business. 54(3), 169-180.

Piperopoulos, P. and Dimov, D. (2015). "Burst bubbles or build steam? Entrepreneurship education, entrepreneurial self-efficacy, and entrepreneurial intentions". Journal of Small Business Management, 53(4), 970-985.

Ramoglou, S., Tsang, E. W. K. (2016). A Realist Perspective of Entrepreneurship: Opportunities as Propensities. Academy of Management Review, 41(3), 410-34. doi: 10.5465/amr.2014.0281.

Robledo, J., Aran, M., Sanchez, V., Molina, M. (2015). The moderating role of gender on entrepreneurial intentions:A TPB perspective. Intangible Capital, 11(1), 92-117.

Ryu, P., Kim, D. (2020). Moderating effect of gender on the opportunity recognition and entrepreneurial intention. Entrepreneurship and Sustainability Issues, 725-740 
Saeed, S., Yousafzai, S.Y., Yani-De-Soriano, M. and Muffatto, M. (2015). "The role of perceived university support in the formation of students' entrepreneurial intention". Journal of Small Business Management, 53(4), 1127-1145.

Santoso, A. B. (2016, February 03). Analysis: Developing high-growth entrepreneurs. Retrieved October 05, 2020, from https://www.thejakartapost.com/news/2016/02/03/developing-highgrowth-entrepreneurs.html

Sarason, Y., T. Dean, and J. F. Dillard. (2006). Entrepreneurship as the Nexus of Individual and Opportunity: A Structuration View. Journal of Business Venturing, 21(3), 286-305. doi: 10.1016/j.jbusvent.2005.02.007.

Sarasvathy S. (2001). Causation and effectuation: Toward a theoretical shift from economic inevitability to entrepreneurial contingency. Academy of Management Review, 26, 243-263.

Schumpeter, J. A. (1934). The Theory of Economic Development: An Inquiry into Profits, Capital, Credit, Interest and the Business Cycle. New Brunswick: Transaction Publishers.

Schumpeter, J. A. (1942). Capitalism, Socialism and Democracy. London: Routledge.

Sekaran, U., Bougie, R. 2016. Research Methods For Business: A Skill Building Approach Seventh Edition. 1st ed. John Wiley \& Sons.

Shane S. \& Venkataraman S. (2000) The promise of entrepreneurship as a field of research. Academy of Management Review, 25(1), 217-226

Shane, S. 2003. The Individual-Opportunity Nexus Approach to Entrepreneurship. Aldershot, Eward Elgar, UK.

Short JC, Ketchen DJ, Shook CL, Ireland RD. (2010). The concept of "opportunity" in entrepreneurship research: Past accomplishments and future challenges. Journal of Management, 36(1), 40-65. doi: 10.1177/0149206309342746.

Stevenson, H.H., Roberts, M.J., Grousbeck, H.I. (1985). New Business Ventures and the Entrepreneur. Irwin, Homewood, IL.

Timmons, J. (1994). New venture creation (4th ed.). Homewood, IL: Richard D. Irwin

Turker, D. and SonmezSelçuk, S. (2009). "Which factors affect entrepreneurial intention of university students?". Journal of European Industrial Training, 33(2), 142-159.

Gender Equality: UNDP in Indonesia. (2017). Retrieved December 18, 2020, from https://www.id.undp.org/content/indonesia/en/home/gender-equality.html

Van Auken, H., Stephens, P., Fry, F. L., \& Silva, J. (2006). Role model influences on entrepreneurial intentions: A comparison between USA and Mexico. The International Entrepreneurship and Management Journal, 2(3), 325-336

Wasdani, K.P., Mathew, M. (2014). Potential for opportunity recognition along the stages of entrepreneurship. J Glob Entrepr Res, 4(7). doi: 10.1186/22517316-2-7

Wei, X., Liu, X. \& Sha, J. (2019). How Does the Entrepreneurship Education Influence the Students' Innovation? Testing on the Multiple Mediation Model. Front. Psychol. 10:1557.

Wood, M. S., and W. Mckinley. (2010). The Production of Entrepreneurial Opportunity: A Constructivist Perspective. Strategic Entrepreneurship Journal, 4(1), 66-84. doi: 10.1002/sej.83. 
Zahra, S. A. (2020). International entrepreneurship in the post Covid world. Journal of World Business, 101143. doi:10.1016/j.jwb.2020.101143 